Gang Activity in English Prisons: The Prisoners' Perspective

\author{
Jane Wood \\ Department of Psychology, \\ Keynes College, \\ University of Kent at Canterbury, \\ Canterbury, \\ CT2 7NP, \\ United Kingdom. \\ E-mail: j.1.wood@kent.ac.uk
}

This research was made possible by a grant from Her Majesty's Prison Service Planning and Research Group.

Running Head: English Prison Gangs 


\section{GANG ACTIVITY IN ENGLISH PRISONS: THE PRISONERS’ PERSPECTIVE}

Gang activity in American prisons has resulted in serious problems for prisoners and staff (e.g. Fong \& Buentello 1991; Stevens 1997). This study assessed prisoners' perceptions of gang-event frequency in the U.K. Interviews with 360 prisoners from 9 prisons in England and Wales indicated gang-related events were perceived as more frequent in all male categories of prison than they were in female institutions. Prisoners reported drug possession and prisoner groups being formed along regional origins as the most frequent gang related activities. Recidivists perceived higher levels of gang related activity than did first time prisoners. Gang related variables also predicted prisoners' perceptions that groups of prisoners have more control over events in the prison than do staff and that order in the prison may not be maintained. The merits of interviewing prisoners and the implications of the results for maintaining order in prison are discussed.

Key words: Prison Gangs, Prison Violence, Order, Control 


\section{ACKNOWLEDGEMENTS}

This study could not have been completed without the efforts of many people. The first group to whom I owe a debt of gratitude is of course, the participants. I should like to thank them for their time and the consideration they gave to the questions. Special thanks go the prison staff who took the time to accommodate the needs of the study. Much is also owed to the governing governors who granted research access even though over stretched resources sometimes made this difficult. In addition, I should like to thank the Prison Service for funding the research. Without this financial support the broad scope of the study would have been particularly difficult. 


\section{INTRODUCTION}

American research indicates that prison gangs have become a formidable feature of many Federal and State prisons (e.g. Buentello, Fong \& Vogel, 1991; Camp \& Camp, 1985; Jacobs, 1977). In the U.K. only one study (Wood \& Adler 2001) has directly examined the issue of prison gangs in the English and Welsh prison estate. It revealed that prison staff perceive many gang-related activities as common occurrences in English prisons. The present study builds on this knowledge by examining prisoners' perceptions of gang-related activities in English prisons.

There is no precise definition of a prison gang; some argue (e.g. Fong \& Buentello, 1991; Huff, 1996) that prison gangs are cohesive groups of prisoners (with a leader), whose criminal activities negatively impact on the prisons that hold them. Others contend that prison gangs have a more flexible configuration (e.g. Camp \& Camp 1985). Also, research has not clarified the minimum number of members for an operational definition of a "prison gang". In light of these gaps in the literature, this study defined a gang by borrowing from Brown's (2000) definition of a group and from Fong and Buentello's (1991) outline of a prison gang. Brown (2000) defines a group as existing when ... "two or more people define themselves as members of it and when its existence is recognised by at least one other." (p.2-3). For pragmatic purposes, since participants may not consider two people to be a group, the number used in the current study was three or more people. A prison gang was therefore defined as a group of three or more prisoners whose negative behaviour has an adverse impact on the prison that holds them.

The largest survey into the existence of prison gangs reported their presence in $60 \%$ of Federal and State prisons (Camp \& Camp, 1985). Prison gangs reportedly 
included 2\% (12,634 prisoners) of the prison population and were thought to be responsible for more than $50 \%$ of prison management problems (Camp \& Camp, 1985) leading in some case to the declaration of a state of emergency (Beaird, 1986; Fong, 1990).

Prison gangs have continued to develop into organisations with connections and activities stretching from prison to the community (Fong \& Buentello, 1991; Sullivan, 1991). They function on the acquisition of money and power (Camp \& Camp, 1985; Fong, 1990) and use threats and violence to dominate staff and other prisoners (Huff, 1996; Irwin, 1980; Stevens, 1997). In the U.S.A. the most common activities of prison gangs are reported to be, [in descending order]: intimidation; drug trafficking; assault; abuse of weaker prisoners; extortion; protection; contraband weapons; theft; "strongarm robbery"; rackets; robbery; prostitution; rape; "sodomy for sale"; murder; bribery; arson; slavery and explosives (Camp \& Camp, 1985). Stevens (1997) found that in a prison where prison gangs were active $73 \%$ of non-gang prisoners wanted a transfer and $87 \%$ would like to ask for protective custody but feared the consequences. Gang members are uninterested in schemes to earn privileges or address offending behaviour (Huff, 1996). However, they generally co-operate with prison staff requests and prison rules and only become violent if opposed by prison staff (Camp \& Camp 1985). On the other hand more recent evidence suggests that gang members are frequently violent and consistently involved in almost all other forms of illicit behaviour (Gaes et al 2002). In the U.K. research reveals high levels of many gang related events such as drug possession; groups formed by race; requests for transfers; prisoner/prisoner assaults; and regional affiliations occur across all categories of prison (Wood \& Adler, 2001). The 
levels of these activities predicted staff perceptions of reduced order and control in the prison.

Nonetheless, there is still a paucity of research into prison gangs. In the U.S.A. researchers note that officials often do not accept that a prison gang problem exists (Fong \& Buentello, 1991). There is also the difficulty of accessing gang members who may abide by a code of secrecy to protect members from official detection and transfer to gang blocks reserved for prison gang members (Camp \& Camp, 1985; Fong \& Buentello, 1991). Calls for a more research-led proactive approach to the management of prison gangs have resulted from the recognition that the existence of prison gangs tends to be recognised only following a crisis and that rectifying the situation is often costly (Fong \& Buentello, 1991). Fong and Buentello (1991) contend that a proactive approach would result in research establishing the existence and activities of prison gangs before they become organised and possibly disruptive.

So far, research has relied mainly on prison staff reports or prison records (e.g. Camp \& Camp 1985; Fong \& Buentello 1991; Huff 1996; Wood \& Adler 2001; Gaes et al 2002).While staff accounts and records may be useful to begin examining prison gangs there will be limitations to the insight prison staff can offer. Canadian research indicates that staff awareness of prisoner activity is limited (Cooley 1993). Prison staff may not be fully aware of the frequency with which certain events occur. Similarly, problems such as low morale, lack of job satisfaction, or even stereotypical views of prisoners' behaviour may colour staff accounts.

The problems associated with staff perspectives also apply to the use of official prison data; a methodology favoured by some (e.g. Camp \& Camp 1985; Buentello Fong and Vogel 1991). If staff assessments of prisoners' behaviour are limited or 
flawed, then prison records compiled by staff will reflect those inaccuracies. Also, the contradictory sources of official information available, i.e. log books, landing books, observation books and adjudication data make prison records an erratic source of evidence.

The most logical alternative to the above methodologies is to ask prisoners for their perceptions of 'gang-related' events in prison. Some American researchers argue that prisoners would not cooperate with this kind of research (e.g. Fong \& Buentello 1991) while others have found that prisoners are willing to report confidentially the activities of prison gangs (e.g. Stevens 1997). Since only a small number of prisoners, 2\% (Camp \& Camp 1985) and 10\% (Knox 1994) are gang members this means that most prisoners are not prison gang members. If prison gangs are as predatory as the literature suggests then non-gang prisoners are likely to have been victimised by these groups. These prisoners, if assured of confidentiality, may be willing to speak to researchers. Also, even prison gang members may not be as reticent as suggested (e.g. Fong \& Buentello 1991) since Koehler (2000) found that more than $90 \%$ of a well organised gang were willing to be interviewed about their gang membership but not about involvement in criminal activity. Consequently, this study built on the work of Wood and Adler (2001) by examining prisoners' perceptions of gang related activity and order and control in the prison.

Although gang related activity in the U.K. may have similar patterns to those observed in the U.S.A. there could also be some fundamental differences. For example, American researchers note how prison gangs form along racial lines, just as street gangs do. In the U.K. street gangs form along regional lines (Mares, 2001) and prison gangs may do the same. Also, there are fundamental differences between the American and 
English and Welsh prison systems that may influence the existence and/or emergence of prison gangs. For example, in Quentin (a high security establishment) the ratio of officers to prisoners is 1:190 and even in the block where prison gangs are known to be active the ratio is 1:16. In English and Welsh prisons, prisoners experience a greater staff presence than their counterparts in the U.S.A. The official ratio of officers to prisoners in England and Wales is one officer per 2.5 prisoners (category B), one officer per 1.3 (category C) one officer per 1.9 (YOI) and one officer per 1.9 (females) (Function Report, H.M. Prison Service 2005). However, these figures may differ between wings in different prisons and so some prisoners may have more supervision than others, even within categories. Nevertheless, the suggestion here is that generally prisoners in the U.K. are supervised to an extent that may hinder the development and functioning of prison gangs.

Taking potential differences into account this study used key indicators of prison gang presence identified by Buentello et al (1991) together with items developed for the English and Welsh prison system by Wood and Adler (2001). Since staff perceptions of prison gang activity related to staff reports of reduced control and order in prison (Wood \& Adler 2001) this study also aimed to see if prisoners' reports reflected a similar relationship between gang event frequency and perceived order and control.

As previous research notes that category $\mathrm{C}$ (medium/low security); Female establishments (classified as open/closed: hold females from 15 years old); Young Offenders' Institutions (male offenders aged 15-21 years) and Category B prisons (medium/high security) are the establishments particularly vulnerable to gang related activity, these were included in this study. Dispersal prisons (Highest security) and 
Open prisons (Low security) were not included since staff reports indicated lower levels of gang-related activity (Wood \& Adler, 2001).

However, it is possible that prisoners' and staff perceptions of gang related activity may differ due to environmental features of the institutions. For instance, some female establishments are designed on the basis of 'houses' and aim to establish a pattern of 'home' and 'the neighbours' (Kelley 1970). In such a penal structure, gang-related activities may occur in isolated pockets throughout the prison, leaving many prisoners oblivious to their occurrence, which may be reflected in the levels of events reported. Prison staff are unlikely to be equally oblivious since their diverse duties provide them with an overall insight into the prison and its events.

Demographic and institutional variables were also examined since American research indicates that gang members have served more sentences, take more drugs and have longer sentences than non gang prisoners (Sheldon 1991). They are also likely to be younger than non gang prisoners (Ralph, Hunter, Marquart, Cuvelier and Merianos 1996). If this also applies to the U.K., it could be expected that prisoners most involved will be able to provide the greatest insight into gang related events, since some gang related events are covert and therefore not as visible to other prisoners or staff. Subsequently, younger prisoners, those serving longer sentences, and recidivists may report higher levels of events. Ethnic origin was included due to self-classification having a possible bearing on how prisoners perceive themselves in terms of race. For example, prisoners of mixed race may consider themselves to be either black or white and if prisoner groups form along racial lines as suggested by gang researchers (e.g. Camp \& Camp 1985) this may influence the prisoner's choice of associates and the information they are privy to. 
Hypotheses:

H1) Since prison staff reported that gang related events were highest in category $\mathrm{C}$ and Young Offender Institutions, it is expected that prisoners will also report these categories as having the highest levels of gang related events. Category B prisoners and female prisoners are expected to report the lowest levels of gang related activity.

H2) It is expected that prisoners will hold similar perceptions to staff inasmuch as those who perceive high levels of gang related events will also perceive prisoner groups as having more control over events in the prison than do staff (prisoner control).

H3) It is expected that prisoners will hold similar perceptions to staff inasmuch as those who perceive high levels of gang related events will also perceive that staff may not maintain order in the prison (staff order).

H4) It is expected that prisoners involved in gang related activity will be more aware of the actual levels of gang related activity and so reports of gang related activity will be predicted from demographic and institutional factors such as age, length of sentence and recidivism.

\section{METHOD}

Participants

Three hundred and sixty prisoners from nine prisons participated (see Table 1 for sample demographics). In eight of the nine prisons every 5 th or 7 th prisoner was selected from a list of all prisoners. In the ninth prison, prisoners were approached and asked to participate by either the researcher or prison staff. Subsequently of the 360 prisoners who took part in this study 40 resulted from opportunistic rather than random sampling. 
Prisoners held on remand were not selected since they were less likely than convicted prisoners to be aware of other prisoners' activities. Of those asked to take part in the research, three prisoners held in category $\mathrm{C}$ institutions and two prisoners in the category B establishment, refused.

\section{TABLE 1 TO GO HERE}

Materials

Interview items were based on the extension of Fong et al's (1991) questionnaire developed by Wood and Adler (2001) and adapted for use with prisoners for this study. Fong et al's original variables included 11 items assessing: prisoner requests for protective custody, prisoners with tattoos, prisoner disciplinary violations of contraband possessions, secret racial groupings of prisoners, the emergence of prisoner cliques, physical assaults on other prisoners, prisoners' involvement in illicit activities with people outside prison, prisoner requests for inter-unit transfers, prisoners' families being threatened by prisoner cliques, verbal threats made to staff by prisoners, physical assaults on staff by prisoners. For clarity, Fong and Buentello's (1991) variable "prisoner possession of contraband" was divided into four specific variables concerning possession of alcohol, drugs, phone cards and tobacco as these were considered to be the most common forms of contraband in English and Welsh prisons.

Variables added by Wood and Adler (2001) were based on knowledge of the English prison system and American findings. Items used to assess the dominance of some prisoners by prisoner groups and the frequency of opposing groups' disputes were 
included since these are likely to be common examples of group behaviour in prison (Wood \& Adler 2001). Wood and Adler's additional items also expanded Fong et al's (1991) racial basis for group formation to include regional and ideological criteria; factors acknowledged as a basis for group formation by American and U.K. researchers (e.g. Camp \& Camp; 1985, Rush, Stone \& Wycoff, 1996; Mares, 2001). For example, prisoners were asked to report levels of membership of extreme political organisations (e.g. The British National Party) and the domination of prisoners' groups by such members. Given that concerns and fear over personal safety have been found to proliferate in English prisons (Adler, 1998), an item was used to assess prisoners' concerns for their safety. Two variables were used to examine prisoners' perceptions of order and control in the prison. The first assessed perceptions that groups of prisoners have more control over events in the prison than do staff and the second assessed perceptions that staff may lose control of the prison. These were based on American findings that prison gangs flourish where they can control staff and other prisoners (Stevens' 1997) and that prison gang presence leads to a breakdown in order (e.g. Beird 1986; Fong 1990). The occurrence of the events alone cannot be taken as an indicator of prison-gang presence (Fong et al. 1991). If a number of events occur "frequently" or "very frequently", or there is a sudden rise in levels of occurrence, then this should give rise to concerns that prison gangs may be operating in the prison. Subsequently prisoners were asked to report the frequency of each event.

Internal reliability analysis indicated that the scale was reliable $(\alpha=.86)$. Although prisoners were asked items relating to groups of three or more, the phrase "prison gang" was not used. This was to avoid experimental demand i.e. the possibility 
that some prisoners may have preconceived ideas about prison gangs, which could influence their responses.

Procedure

Interviews were conducted individually and in private. Participants were fully briefed of the study's aims and their rights to confidentiality and anonymity before interviews began. At the request of the Prison Service, participants were told before the interview that if they revealed an intention to escape, harm themselves or another person, this information could not remain confidential. To control for an order effect, items on the questionnaires were rotated to produce 4 different versions. Respondents were randomly presented with one of the 4 versions. Questions were read to participants to allow for any literacy difficulties and respondents were asked to report only events that had occurred in the current prison within the last six months. Each interview lasted approximately 20 minutes after which participants were invited to ask questions before being debriefed verbally and in writing.

\section{RESULTS}

To get a clearer idea of the type and frequency of gang-related events, the percentage of prisoners who reported an event as occurring frequently (11-20 times) or very frequently (more than 20 times) within the preceding 6 months were calculated. As Table 2 shows, the event considered by prisoners to be the most frequent was prisoners possessing drugs. Other common events seem to function on cohesion of groups or possession of material goods and seem to occur more frequently than do events relating to domination of, or altercations between, prisoners.

INSERT TABLE 2 ABOUT HERE 
To examine categories of prison according to perceptions of gang-related events, individual scores for each event were summed to give a total for each participant. A one-way ANOVA revealed a difference between perceived levels of events according to category of prison, $\mathrm{F}(3,355)=4.46, \mathrm{p}<.005, \eta=.04$, power $=.88$. Tukey's post hoc analysis revealed that male prisoners in Categories $B(M=58.15), C(M=57.37)$, and YOI $(M=58.17)$ reported similar levels of events, but female prisoners reported fewer gang-related events $(\mathrm{M}=51.33)$ than all other categories.

Gang events as predictors of reduced order and control in prison

The data were analysed to see if prisoners who perceived high levels of gang related events also perceived high levels of prisoner control and a reduction in staff order. Although the variables 'prisoner control' and 'staff order' were assessed as part of the gang events scale they were used only as D.V.'s for the purpose of analysis. Perceptions of 'prisoner control'

To see if prisoners who perceived high levels of gang related events also considered prisoner groups to have more control over events in the prison than do staff, (prisoner control) a standard regression analysis using gang related events as IV's and prisoner control as the DV was conducted. Results revealed the independent variables successfully predicted the DV and explained $13 \%$ of the variance (see Table 3). The Beta coefficients for the important predictors reveal that as each predictor increases so too do perceptions that prisoners have more control over events in the prison than do staff. 
INSERT TABLE 3 ABOUT HERE

\section{Perceptions of 'staff order'}

The second standard regression analysis used prisoners' perception that staff might not maintain order in the prison' (staff order) as the DV and prisoners' perceptions of gang events as the IV's. Results showed that the IV's successfully predicted the DV accounting for $29 \%$ of the variance (see Table 4). Beta values indicated, with one exception, that as each IV increases so too do prisoners' perceptions that staff may not maintain order in the prison. The IV prisoners belonging to outside organisations dominating prisoner groups has a negative Beta value indicating that this variable has a negative relationship with reduced staff order.

\section{INSERT TABLE 4 ABOUT HERE}

Perceptions of gang event frequency and demographic/institutional characteristics

A standard regression analysis was used to see if demographic and institutional characteristics related to prisoners' perceptions of gang events. The total score for perceived level as of gang-related events was used as the DV and age, ethnic origin, gender, number of prison sentences served and length of the current sentence were used 
as IVs. Since $46.4 \%$ of participants were serving a first prison sentence the number of prison sentences served was split into prisoners serving a first prison sentence (naïve) and prisoners serving a subsequent prison sentence (recidivist). The analysis showed that prisoners perceiving the highest levels of gang related events were young, male and recidivists.

\section{INSERT TABLE 5 ABOUT HERE}

\section{DISCUSSION}

This study had four hypotheses, two were supported by the results and two were partially supported. The first hypothesis anticipated that reports of gang-related events would be highest in category C prisons and Young Offender Institutions. Category B prisoners' and female prisoners' reports would be the lowest. Only partial support was found for this prediction. Although gang-related events were perceived as more frequent in all male categories of prison than they were in female institutions, male institutions did not differ from each other.

This finding echoes American observations that female prisoners are not as involved as male prisoners in prison gang activity (e.g. Knox 1994). Female prisoners' reports of events also seem to differ from levels reported by prison staff in the Wood and Adler (2001) study. Wood and Adler's findings suggested that female establishments did not differ from male establishments with the exception of category $\mathrm{C}$ prisons. As noted earlier some female establishments reflect a neighbourhood structure (Kelley 1970), which may mean that gang-related activities occur in isolated pockets leaving some 
prisoners less aware of gang related activity than staff. Equally, if the prison replicates a 'neighbourhood' then cohesive group formation could be a normal feature of the environment rather than a matter of prisoner choice. Of the two female prisons that took part in this study, one was organised according to 'houses.' Hence, it is feasible that the influence of this one establishment was sufficient to shape the results.

The second hypothesis predicted that the frequency of gang related events would predict prisoners' perceptions of prisoner groups having more control over events in the prison than did staff. This prediction was supported. As expected, gang related variables predicted prisoners' perceptions of groups of prisoners having more control over events than do staff. This supports American and British findings that activities associated with prison gangs relate to prisoners having increased control over events in the prison (Camp \& Camp, 1985; Fong \& Buentello, 1991; Stevens, 1997; Wood \& Adler, 2001).

The key predictors of 'prisoner control' included a combination of overt and covert gang-related activities. Overt events included verbal threats to staff and groups of prisoners verbally dominating other prisoners. These indicate intimidation of other individuals; a central feature of the prison gang (e.g. Camp \& Camp 1985). Another important predictor of prisoner control was requests for protective custody. This supports previous findings that requests for protective custody rise when prison gangs are present due to threats, assaults and intimidation experienced by non gang prisoners (Stevens 1997).

The possession of alcohol as an important predictor of 'prisoner control' is interesting. Unlike many contraband materials such as drugs, alcohol is a relatively bulky product and not easy to conceal so it may require a level of freedom or resourcefulness to prevent staff finding it. A certain level of expertise or freedom would 
also be necessary to produce it inside or import it into, the prison. If prisoners have high levels of control over events in the prison, then the procurement and concealment of alcohol is likely to be easier. Of course there is always the alternative explanation that in an environment where prison staff sense they lack full control, some may be tempted to overlook the odd bottle of 'hooch.' In such circumstances, it would be surprising if prisoners did not report beliefs that prisoners have more control over events in the prison than do staff.

Prisoners forming close knot groups as a key indicator of 'prisoner control' within the prison is not unexpected. What is not clear is whether close knit groups result from or contribute to, high levels of 'prisoner control.' It is possible that they do both. For example, prisoners intent on gaining and maintaining power may form groups as increased numbers may help achieve this aim. These groups may then begin to exert their own 'prisoner control' as they recognise and capitalise on their potential for power within the prison. As their control increases other prisoners may band together for protection and more close knit groups develop. Formation of groups for protection from the perceived threat of other groups is well documented in American research (e.g. Knox 1994; Klein 1995). As a result they may then develop into a prison gang (Buentello et al, 1991). In such an atmosphere it is only to be expected that prisoners would conceive 'prisoner control' as high.

The third hypothesis predicted that the frequency of gang related events would predict prisoners' perceptions that staff may not maintain order (staff order). This prediction was also supported. This supports American and British findings that gang activity is associated with reduced order in the prison (Camp \& Camp, 1985; Fong \& Buentello, 1991; Stevens, 1997; Wood \& Adler, 2001). Unsurprisingly, physical 
assaults on staff and verbal threats to staff were important predictors of 'staff order.' In an atmosphere where prisoners feel able to verbally threaten and particularly if they feel able to physically assault staff, it could be argued that order is already ebbing away. The importance of more covert variables such as threats to prisoners' families is interesting, as it was one of the less frequent activities cited by prisoners. Its importance as a predictor of 'staff order,' may indicate a subtle effect of gang behaviour on 'staff order' in the prison. If groups of prisoners threaten prisoners' families, then this is most likely to occur during visiting time. This suggests that staff do not have full control over prisoners during visits and so do not maintain full order. Other important predictors of staff order included prisoner membership of outside organisations such as the B.N.P., prisoners who belong to such organisations dominating prisoners groups and secret racial groupings of prisoners. This seems to suggest that there may be racial tensions between prisoners that are either not detected or not adequately dealt with by staff leading to perceptions of a lack of staff order. The nature of the relationship between prisoners forming secret racial groupings and the presence and domination of groups by individuals belonging to organisations such as the B.N.P. is not clear. The results suggest that belonging to organisations such as the B.N.P. positively relates to a reduction in staff order but domination of prisoner groups by these members negatively relates to reduced staff order. It could be that racial groupings form as a response to the perceived threat of white supremacist ideology and so white supremacist ideology is unable to gain a foothold where secret racial groupings exist. Equally, it could be that when prisoners perceive staff as not fully in control of the prison, they perceive other prisoners as a greater threat and band together for protective purposes. Either way, these findings give cause for concern that racial tensions may exist or form between prisoners 
in an atmosphere where prisoners perceive that prison staff may not maintain order in the prison.

The fourth hypothesis anticipated that Prisoners' perceptions of event frequency would be shaped by their demographic/institutional characteristics. Ethnic origin and length of sentence did not relate to responses, but age and number of sentences served linked to prisoners' perceptions of gang related events. Younger prisoners reported higher levels of gang related events than did older prisoners. However, this was not sufficient to cause a difference between young offender institutions and adult institutions so it seems that many prisoners perceiving gang events as frequent are over the age of 21. Quite why younger prisoners would report higher levels of gang-related events is not clear. Staff reports indicate that younger prisoners are involved in more visible/overt gang-related behaviours than older prisoners (Wood \& Adler, 2001). It may be the case that the activities of younger prisoners are more easily observed by their peers and are therefore more easily reported, but this is not limited to young offender institutions alone.

Recidivists were also more likely to report higher levels of events than were naïve or first time prisoners. Recidivists have more experience of in prison life and this may mean they have more awareness of the less obvious gang-related activities. Yet, it could be argued that prisoners serving longer sentences would also have more awareness but the results show this is not the case. As speculated earlier, this may be due to personal activity. If recidivists and younger prisoners are more personally involved in gang related activity, it makes sense that they would be more aware of the actual levels of events than non involved prisoners. It would be unrealistic to expect that even in a relatively small environment such as a prison that all prisoners would know of 
all the activities taking place around them. It is only to be expected that prisoners involved in illicit activities would try to keep their behaviour as inconspicuous as possible to avoid detection by prison staff. As a result, prisoners not involved in the events are unlikely to be aware of the full extent of prison groups' activities. Perhaps prisoners who have been victimised may have more awareness, but even they are likely to know less than group members, since not all activities involve victimising other prisoners. This may be reflected in the current results. Further work would be needed to clarify these possibilities.

Although asking prisoners about prisoner activity has the potential to reveal important information, there will inevitably be limitations. There will be limitations to the amount of information prisoners are prepared to share, the amount of information prisoners actually have and the methodological constraints imposed by the questions they are asked. Also, there are likely to be methodological constraints in terms of sampling methods. As noted earlier, one of the nine prisons was unable to allow random sampling of prisoners and so 40 of the 360 participants were recruited following approaches from the researcher or prison staff. Consequently, it is possible that this volunteer sample did not include segregated or problem prisoners who might not be given freedom on the wings. However, since participation was voluntary all prisoners had the right to refuse to take part in the study and so research of this kind always runs the risk that the sample will to some extent, be self selecting.

Similarly, it must be borne in mind that forensic populations are likely to include individuals reluctant to divulge information to people whom they may regard as authority figures. Even if prisoners offered candid responses, it still remains that perceptions will be subject to memory lapses or inattention on the part of the 
respondent. Consequently, it is feasible that even the most sincere responses will be coloured by cognitive processes that are difficult to overcome.

Nevertheless, the current study was designed bearing many of these issues in mind. Interviews with prisoners were conducted in private and participants were assured, with the exceptions stated before the interview, of confidentiality and anonymity consistent with the ethical demands of psychological research. Under these conditions, it seemed that prisoners spoke unreservedly about their observations. The results do not indicate, as American researchers (e.g. Camp \& Camp 1985; Fong 1990) have suggested, that interviewing prisoners is not a useful method for examining prison gang activities. Given the inherently difficult nature of research in a prison setting, prisoner reports certainly seem to offer one of the most effective ways of developing an understanding of prison populations.

Future work could continue to address the issue of gang related activity in prison by examining prisoners' personal involvement in gang related activity. Certainly, there would be more ethical problems and methodological limitations to asking prisoners about personal involvement. The use of self report may mean that some will 'fake good' rather than admit involvement in criminal activity while in prison. Similarly, there are likely to be ethical problems arising from the information that prisoners disclose. These problems can be reduced if prisoners are fully informed of the kind of information that cannot remain confidential. However, any study that has ethical exceptions is likely to also have constrained results. On the other hand, the current study shows that prisoners can offer valuable insight and if we are to further knowledge in this area, prisoners are a useful source of information to understand more about the formation and function of prisoners' groups. Indeed, not all groups will be involved in gang related activity so we 
need to understand the purposes of different groups before we can devise policies and interventions, if necessary.

This study reveals that prisoners perceive events associated with gang-related activity are wide-spread in England and Wales. These findings echo claims that prison staff perceive high levels of gang related events (Wood \& Adler, 2001). Importantly, both studies reveal that increased levels of gang related events relate strongly to beliefs that prisoners control events in the prison and staff may be unable to maintain order. Certainly, some of the activities prisoners reported e.g. drug trafficking necessitate some degree of prisoner autonomy, whereas others, such as assaults on staff, are consistent with a less than ideal level of staff control. As mentioned earlier it is possible that the higher levels of staff per prisoner in U.K. compared to the U.S.A. may impede the development of gang activity in English and Welsh prisons. Indeed, if staff and prisoners are to have confidence that staff are able to maintain order in the prison then it would make sense to increase staff levels.

Nevertheless the paucity of research into prison gangs in the U.K. prevents the current findings from being placed in context and so it remains unclear whether gang related activity in prisons is a recent development or if similar levels have existed across time. The implications from the current findings are that where levels of gang related events are already high they are likely to become even higher as prisoners form groups in response to existing groups (Knox, 1994). Indeed, this study's findings that secret racial groupings and prisoner membership of white supremacist groups suggests that counter groups may already be in existence. The implication here is that such a situation is likely to worsen rather than lessen and that prisons may become increasingly 
English Prison Gangs

vulnerable to prison gang development, gang related activity and a reduction in order and control. 


\section{$\underline{\text { References }}$}

Adler, J., (1994), Fear in Prisons: A Discussion Paper, London: Prison Reform Trust.

Beaird, L. H. (1986). Prison gangs: Texas. Corrections Today, 1818 - 31.

Brown, R., (2000), Group Processes Dynamics within and between Groups, Oxford, Blackwell.

Buentello, S., Fong, R. S. and Vogel, R. E. (1991) Prison Gang Development: A Theoretical Model, The Prison Journal, LXX1 (2) 3 - 9.

Camp, G. M. and Camp C. (1985). Prison Gangs: Their Extent, Nature and Impact on Prisons. U.S. Dept. of Justice, Washington DC: US. Government Printing Office.

Cooley, D. (1993) Criminal victimizaton in male federal prisons. Canadian Journal of Criminology, 35, 479-495.

Fong, R. S. (1990). The organizational structure of prison gangs: A Texas case study. Federal Probation, 54 (1) 36 - 43.

Fong, R. S. and Buentello, S. (1991). The Detection of Prison Gang Development. Federal Probation, 55_(1) 66 - 69. 
Gaes, G.G., Wallace, S., Gilman, E., Klein-Saffran, J., Suppa, S., (2002), The Influence of Prison Gang Affiliation on Violence and Other Prison Misconduct. The Prison Journal 82, 359-385.

Huff, C. R. (1996). Gangs in America (2 ${ }^{\text {nd }}$ ed.). Newbury Park, CA: Sage.

Irwin, J. (1980). Prisons in Turmoil. Boston: Little, Brown and Company Ltd.

Jacobs, J. (1977). Stateville: The penitentiary in mass society. London: University of Chicago Press.

Kelley, J. (1970). The New Holloway. Prison Service Journal, 10 37-42.

Klein, M.W., (1995). The American street gang: Its nature, prevalence, and control. New York: Oxford University Press.

Koehler, R., (2000), the organizational structure and function of La Nuestra Familia within Colorado state correctional facilities. Deviant Behavior, 21, 155-179.

Knox, G. (1994). An Introduction to Gangs. (3rd Ed). Bristol: Wyndham Hall Press. 
Mares, D., (2001), Gangstas or Lager Louts? Working Class Street Gangs in Manchester. In Klein, M.W., Kerner, H.J., Maxson, C.L., \& Weitekamp, E.G.M. (Eds) (2001) The Eurogang Paradox. The Netherlands, Kluwer.

Ralph, P., Hunter, R.J, Marquart, J.W., Cuvelier S.J., Menanos, D. (1996). Exploring the Differences Between Gang and Nongang Prisoners. In Huff R.C. (Ed.) (1996) Gangs in America ( $2^{\text {nd }}$ Edition). Thousand Oaks, Sage.

Rush, J., Stone, S., and Wycoff, J. (1996). A Preliminary Report of Gang Activity in State Run Juvenile Facilities. Paper presented at the Academy of Criminal Justice Services annual conference Las Vegas, NE. Cited in Stevens, D. J. (1996), Gangs in North Carolina Prisons. Manuscript submitted for publication.

Sheldon, R.G. (1991). A Comparison of Gang Members and Non-Gang Members in a Prison setting. The Prison Journal Vol. LXX1, 2, 50-60.

Stevens, D. J. (1997). Origins of prison gangs in North Carolina. Journal of Gang Research, 4 (4) 23-35

Sullivan, M., (1991). Crime and the social fabric. In J. Mollenkopf and M. Castells (Eds). The Dual City. New York: Russell Sage. 
Wood, J., \& Adler, J., (2001), Gang Activity In English Prisons: The Staff Perspective, Psychology, Crime and Law, 7, 2, 167-192. 
Category of prison

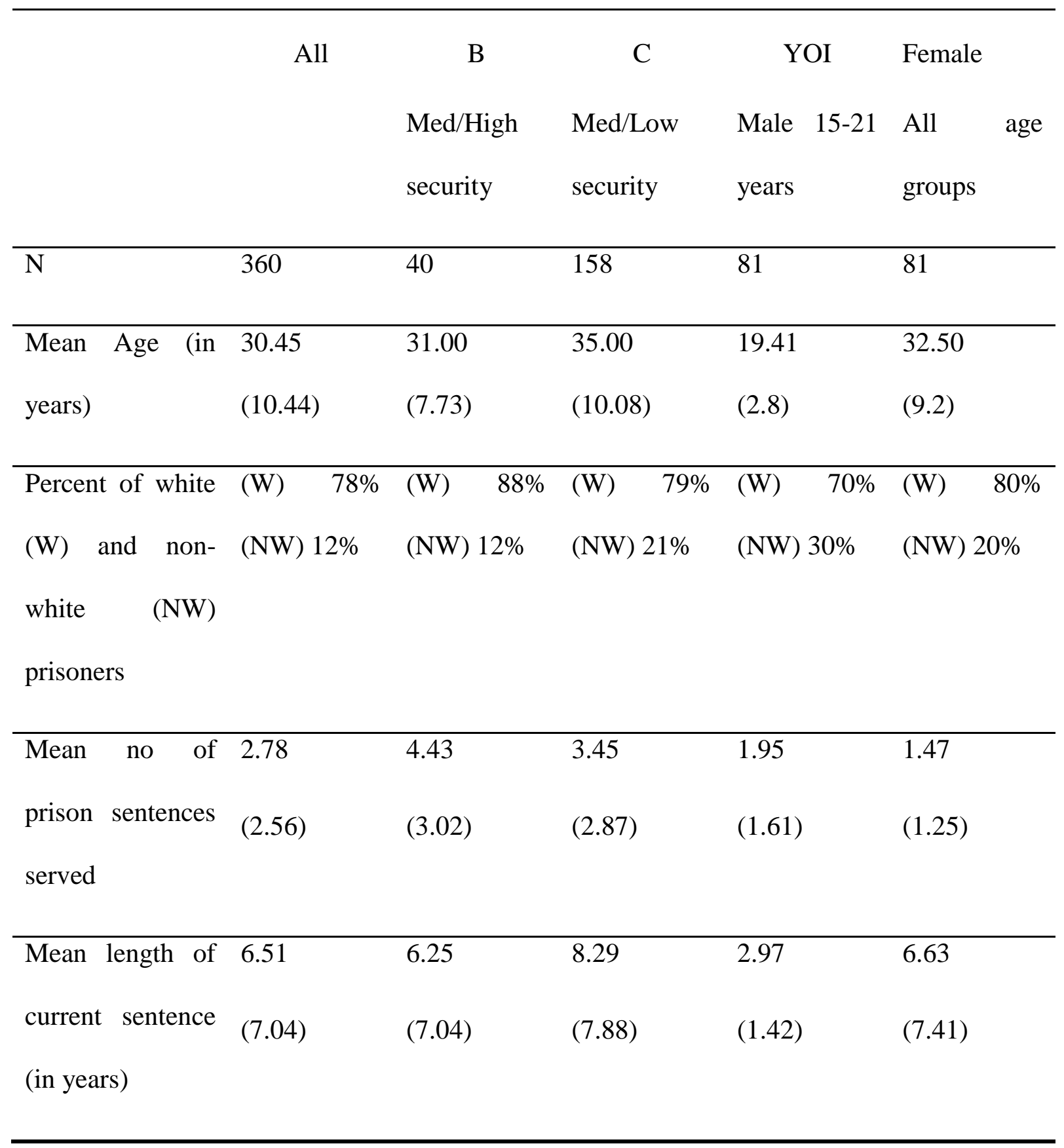

$\underline{\text { Table 1: Demographic and Institutional characteristics of participants }}$ 
Table 2: Percentage of prisoners reporting event as frequent (11-20 times) or very frequent (20+ times) in previous 6 months

\begin{tabular}{lll}
\hline Gang-related variable & Percentage & N \\
\hline Prisoners possessing drugs & 70.7 & 254 \\
Prisoners with more phone cards than allowed & 49.9 & 179 \\
Groups forming according to home location & 49.7 & 178 \\
Prisoners with more tobacco than allowed & 46.1 & 165 \\
Group formation according to race & 45.8 & 164 \\
Formation of close-knit groups & 44.1 & 158 \\
Requests for transfer within prison & 44.0 & 158 \\
Verbal domination of prisoners by groups & 38.9 & 140 \\
Requests for protective custody & 29.6 & 106 \\
Groups arguing over material possessions & 23.5 & 84 \\
Possession of alcohol & 20.6 & 74 \\
Physical domination by groups & 17.0 & 61 \\
Prisoners involved in outside gang activity & 12.3 & 44 \\
Physical assaults on prisoners by groups & 12.3 & 44 \\
Groups verbally threatening staff & 11.2 & 40 \\
Secret racial groupings & 7.5 & 27 \\
Groups having more control over events in prison than staff & 6.1 & 21 \\
Groups threatening the safety of staff & 5.8 & 20 \\
Belief that staff might lose control of prison & 4.5 & 16 \\
Tattoos indicating gang membership & 4.2 & 15 \\
Prisoners belonging to outside organisations (e.g. British & 4.2 & \\
National Party) & & \\
& & \\
\hline
\end{tabular}


Concerns for personal safety

Prisoners' families being threatened by prisoner groups

1.4 5

Groups physically assaulting staff

0.8 2

Members of outside organisations such as British National 0.6 2

Party attempting to dominate prisoner groups 
Table 3: Beta coefficients predicting 'prisoner control'

\begin{tabular}{|c|c|c|c|}
\hline Variable & $\beta$ & $\mathrm{t}$ & $\mathrm{p}$ \\
\hline Prisoners possessing alcohol & .13 & 2.19 & .030 \\
\hline Prisoners requesting protective custody & .13 & 2.22 & .027 \\
\hline Prisoner groups verbally threatening staff & .18 & 2.74 & .007 \\
\hline $\begin{array}{l}\text { Groups of prisoners verbally dominating other } \\
\text { prisoners }\end{array}$ & .15 & 2.18 & .030 \\
\hline Prisoners forming close knit groups & .12 & 1.99 & .047 \\
\hline
\end{tabular}


$\underline{\text { Table 4: Beta coefficients predicting 'Staff order' }}$

\begin{tabular}{|c|c|c|c|}
\hline Variable & $\beta$ & $\mathrm{t}$ & $\mathrm{p}$ \\
\hline Prisoner groups physically assaulting staff & .17 & 3.18 & 0.002 \\
\hline Families threatened by prisoner groups & .23 & 4.45 & 0.000 \\
\hline Prisoner groups verbally threatening staff & .29 & 4.93 & 0.000 \\
\hline $\begin{array}{l}\text { Prisoners belonging to outside organisations such as the } \\
\text { British National Party }\end{array}$ & .15 & 2.21 & 0.028 \\
\hline $\begin{array}{l}\text { Prisoners belonging to outside organisations dominating } \\
\text { prisoner groups }\end{array}$ & -.12 & -1.97 & .049 \\
\hline Secret racial groupings of prisoners & .11 & 2.08 & .038 \\
\hline
\end{tabular}


$\underline{\text { Table 5: Demographic and institutional variables and perceptions of gang related events }}$

\begin{tabular}{|c|c|c|c|}
\hline Variable & $\beta$ & $\mathrm{t}$ & $\mathrm{p}$ \\
\hline Age & -.13 & -2.15 & .032 \\
\hline Gender & -.14 & -2.53 & .012 \\
\hline Number of sentences served & .18 & 3.31 & .001 \\
\hline Adj. $\mathrm{R}^{2}=.07$, df 5,347 & & $\mathrm{p}<0.001$ & \\
\hline
\end{tabular}

